\title{
Laba Ditahan, Laba Operasi, Aliran Kas Operasi, Leverage, Profitabilitas Dan Pengaruhnya Pada Peringkat Obligasi
}

\author{
Putu Kepramareni*, Sagung Oka Pradnyawati dan Made Ardinda Rika Pratiwi \\ Universitas Mahasaraswati Denpasar \\ *pkepramareni@yahoo.co.id
}

\section{How to cite (in APA style):}

Kepramareni, P., Pradnyawati, S, O., Pratiwi, M, A, R. (2021). Laba Ditahan, Laba Operasi, Aliran Kas Operasi, Leverage, Profitabilitas Dan Pengaruhnya Pada Peringkat Obligasi. Wacana Ekonomi (Jurnal Ekonomi, Bisnis dan Akuntansi). 20 (1), pp.28-27. https://doi.org/10.22225/we.20.1.3158.28-37

\begin{abstract}
Companies in carrying out their activities need funds or capital obtained through the money market and the capital market. The capital market allows investors to have various investment options according to their risk preferences where companies can issue financial instruments in the capital market to obtain funds. This is one of the functions of the capital market which facilitates the transfer of funds from parties of surplus to parties in need of funds. One of the related financial instruments in the market is a fund is a drawback. Eligibility for a withdrawal can be seen through an independent body that can rate the resignation. There are several factors that can influence your resignation. According to (Syaifullah \& Soemantri, 2016), income and profitability have a positive effect on negotiations but are different from Susilowati and Sumarto (2010) who found that profitability and operating profit have no effect on negotiating research results on the influence of profit, operating cash flow and leverage on negotiations were also found. in research conducted by Adrian (2010), (Estiyanti \& Yasa, 2012) and Sihombing and Rachmawati (2015). This study aims to obtain empirical evidence regarding the effect of profit on, operating profit, operating cash flow, leverage and profitability as some of the factors that influence bargaining. The population in this study are companies that publish and are listed on the IDX in 2017-2019. The sampling method used in this study was purposive sampling. Logistic regression is used to test the hypothesis. The results showed that profitability had a positive effect on approval. Meanwhile, profit profit, operating profit flow, operating flow and leverage have no effect on resignation.
\end{abstract}

Keywords: Leverage; Operating Cash Flow; Operating Profit; Profitability and Bond Rating; Retained Earnings

\begin{abstract}
Abstrak
Perusahaan dalam menjalankan aktivitasnya membutuhkan dana atau modal yang umumnya diperoleh melalui pasar uang dan pasar modal. Pasar modal memungkinkan investor memiliki berbagai pilihan investasi yang sesuai dengan preferensi risikonya dimana perusahaan dapat menerbitkan instrumen keuangan di pasar modal untuk memperoleh dana. Inilah salah satu fungsi pasar modal yang memfasilitasi transfer dana dari pihak surplus kepada pihak yang membutuhkan dana. Salah satu instrumen keuangan yang diperdagangkan di pasar modal adalah obligasi. Kelayakan sebuah obligasi dapat dilihat melalui lembaga independen yang dapat memberikan peringkat pada obligasi. Terdapat beberapa faktor yang dapat mempengaruhi peringkat obligasi. Menurut (Syaifullah \& Soemantri, 2016) laba ditahan dan profitabilitas berpengaruh positif terhadap peringkat obligasi namun berbeda dengan Susilowati dan Sumarto (2010) yang menemukan hasil bahwa profitabilitas dan laba operasi tidak berpengaruh terhadap peringkat obligasi, perbedaan hasil penelitian mengenai pengaruh laba ditahan, aliran kas operasi dan leverage pada peringkat obligasi juga ditemukan pada penelitian yang dilakukan oleh Adrian (2010), (Estiyanti \& Yasa, 2012) serta Sihombing dan Rachmawati (2015). Penelitian ini bertujuan untuk memperoleh bukti empiris mengenai pengaruh laba ditahan, laba operasi, aliran kas operasi, leverage dan profitabilitas sebagai beberapa faktor yang mempengaruhi peringkat obligasi. Populasi dalam penelitian ini adalah perusahaan manufaktur yang menerbitkan obligasi dan terdaftar di BEI tahun 2017-2019. Metode pengambilan sampel yang digunakan dalam penelitian ini adalah purposive sampling. Regresi logistik digunakan untuk menguji hipotesis.Hasil penelitian menunjukkan bahwa profitabilitas berpengaruh positif terhadap peringkat obligasi. Sedangkan laba ditahan, laba operasi, arus kas operasi dan leverage tidak berpengaruh terhadap peringkat obligasi.
\end{abstract}

Kata Kunci: Leverage; Aliran Kas Operasi; Laba Operasi; Profitabilitas dan Peringkat Obligasi; Laba Ditahan 


\section{PENDAHULUAN}

Obligasi merupakan salah satu sumber pendanaan (financing) bagi pemerintah dan perusahaan yang dapat diperoleh dari pasar modal (Junaedi, 2016). Obligasi (bond) merupakan suatu kontrak yang mengharuskan peminjam untuk membayar kembali pokok pinjaman ditambah dengan bunga dalam kurun waktu tertentu yang sudah disepakati (Jogiyanto,2010:217). Menurut Brigham, et al., (2011) obligasi sering dipandang sebagai investasi yang relatif aman, tetapi tidak tertutup kemungkinan investor mengalami kerugian baik yang berasal dari faktor diluar kinerja perusahaan maupun faktor internal perusahaan, misalnya risiko dana jatuh tempo tidak terbayar tepat waktu.

Obligasi sebelum ditawarkan, harus diperingkat oleh suatu lembaga atau agen pemeringkat obligasi (rating agency). Lembaga independen, obyektif dan dapat dipercaya yang memberikan informasi pemeringkat skala risiko dan didalamnya terdapat sekuritas obligasi yang berfungsi sebagai petunjuk sejauh mana keamanan suatu obligasi bagi investor disebut dengan Agen Pemeringkat Obligasi. Keamanan tersebut ditunjukkan oleh kemampuan suatu perusahaan dalam hal membayar bunga dan melunasi pokok pinjaman. Sehingga bisa menggunakan jasa agen pemeringkat obligasi tersebut untuk mendapatkan informasi mengenai peringkat obligasi. Peringkat obligasi menyatakan skala risiko atau tingkat keamanan suatu obligasi yang diterbitkan. Lebih lanjut, (Raharja \& Sari, 2008) mengungkapkan bahwa peringkat obligasi ini penting karena peringkat tersebut memberikan pernyataan yang informatif dan memberikan sinyal tentang probabilitas kegagalan hutang suatu perusahaan.

Investor dapat menilai tingkat keamanan suatu obligasi berdasarkan informasi yang diperoleh dari agen pemeringkat (Rika, Budiatmanto, Prabowo, \& Arifin, 2011). Salah satu agen pemeringkat obligasi di Indonesia adalah PT PEFINDO (Pemeringkat Efek Indonesia). Tugas utama PT PEFINDO adalah untuk menyediakan suatu peringkat atas risiko kredit yang objektif, independen serta dapat dipertanggung jawabkan atas penerbitan surat hutang yang diperdagangkan kepada masyarakat luas. Objek PEFINDO hanya memperingkat efek utang dan perusahaan. Peraturan di Bursa Efek Indonesia menyebutkan bahwa emiten yang akan melakukan pencatatan efek bersifat utang di bursa wajib memenuhi salah satu ketentuan yaitu hasil pemeringkatan efek dari lembaga pemeringkat efek yang terdaftar di BAPEPAM-LK sekurang-kurangnya BBB- (investment grade).

Menurut Mahfudhoh dan Cahyonowati (2014) salah satu faktor yang dapat mempengaruhi peringkat obligasi adalah laba ditahan. Laba ditahan adalah akumulasi penghasilan sebuah perusahaan setelah dikurang dengan dividen. Laba ditahan (retained earning) merupakan salah satu dari sumber dana yang paling penting untuk membiayai pertumbuhan perusahaan sehingga dapat dijadikan indikator bagi perusahaan untuk memberikan sinyal kepada investor mengenai kemampuannya dalam membayar kewajibannya (Riyanto, 2011). Selain laba ditahan menurut (Yuliana, 2011) faktor lainnya yang dapat mempengaruhi peringkat obligasi adalah laba operasi. Laba operasi ini menggambarkan aktivitas operasi perusahaan telah dijalankan dan dikelola secara baik dan efisien. Laba operasi (operating income) merupakan suatu pengukuran laba perusahaan yang berasal dari aktivitas operasi yang masih berlangsung (Wild \& Subramanyam, 2009). Angka laba operasi adalah selisih laba kotor dengan biaya-biaya operasi (Kieso, 2018).

Selanjutnya (Yasa, 2010), menyatakan bahwa variabel yang dapat mempengaruhi peringkat obligasi adalah aliran kas operasi. Aliran kas operasi merupakan arus kas yang berasal dari aktivitas operasi perusahaan. Menurut (Kieso, 2018) arus kas dari transaksi yang digunakan untuk menentukan laba bersih. Sedangkan menurut Burton (2000) menyatakan bahwa aliran kas operasi berhubungan dengan tingkat likuiditas yang tinggi yang akan menunjukkan kuatnya kondisi keuangan perusahaan sehingga secara finansial akan mempengaruhi peningkatan prediksi peringkat obligasi. Arus kas diklasifikasikan menjadi tiga yaitu arus kas dari kegiatan operasi, arus kas dari kegiatan investasi, dan arus kas dari kegiatan pembiayaan (Mahendra, 2014). Penelitian yang dilakukan oleh (Raharja \& Sari, 2008) menyatakan bahwa leverage berpengaruh positif terhadap peringkat obligasi. Leverage merupakan rasio keuangan yang menunjukkan proporsi penggunaan utang untuk membiayai investasi terhadap modal yang dimiliki. Rasio ini digunakan untuk mengukur sejauh mana perusahaan menggunakan utang dalam membiayai investasinya. Perusahaan yang tidak mempunyai leverage berarti menggunakan modal sendiri 100\% (Wisnu 2012). Semakin tinggi rasio ini berarti sebagian besar aset didanai dari hutang. Kondisi tersebut menyebabkan perusahaan dihadapkan pada default risk atau peringkat obligasi yang rendah. 
Linandari (2010) menggunakan profitabilitas sebagai salah satu indikator penting diperhatikan untuk menilai peringkat obligasi di masa datang adalah dengan melihat sejauh mana pertumbuhan profitabilitas perusahaan. Indikator ini sangat penting diperhatikan untuk mengetahui investasi yang akan dilakukan investor di suatu perusahaan mampu memberikan return yang sesuai dengan tingkat yang disyaratkan investor, salah satunya dengan menggunakan ROA Return on Assets(Tandelilin, 2001 dalam Luky dan Sumarto, 2010:166). Adrian (2011) yang menyimpulkan bahwa profitabilitas tidak berpengaruh positif pada peringkat obligasi dan penelitian Manurung, dkk. (2016) yang menemukan bahwa profitabilitas berpengaruh positif pada peringkat obligasi. Menurut Malia (2015) semakin tinggi tingkat profitabilitas perusahaan maka semakin rendah risiko ketidakmampuan membayar (default), sehingga semakin baik peringkat yang diberikan terhadap perusahaan tersebut. Pada penelitian ini diproksikan dengan menggunakan pengukuran dari profitabilitas yang diinterpretasikan dengan ROA memberikan pandangan manajemen untuk mengendalikan pengeluaran secara efektif (Riyanto, 2011).

\section{TINJAUAN PUSTAKA}

\section{Teori Sinyal}

Signalling theory menjelaskan bahwa perusahaan untuk memberikan informasi laporan keuangan pada pihak eksternal adalah terkait dengan adanya asimetri informasi antara pihak manajemen perusahaan dengan pihak luar dimana pihak manajemen perusahaan memiliki banyak informasi serta mengetahui prospek perusahaan di masa yang akan datang (Sari \& Bandi, 2010). Informasi yang dibutuhkanoleh para investor untuk menentukan apakah investor tersebut akan menanamkanmodalnya atau tidak. Hal ini dikarenakan sebelum dan sesudah melakukaninvestasi, banyak hal yang harus dipertimbangkan oleh investor. Teori iniberfungsi untuk memberikan kemudahan bagi investor untuk mengembangkanmodalnya yang dibutuhkan oleh perusahaan dalam menentukan arah prospek perusahaan ke depan (Afiani, 2013). Teori sinyal menjelaskan mengapa perusahaan mempunyai dorongan untuk memberikan informasi laporan keuangan pada pihak luar, salah satunya adalahuntuk keperluan pasar modal.

Perusahaan mengetahui lebih banyak mengenai perusahaan dan prospek yang akan datang daripada pihak luar (investor dan kreditor). Kurangnya informasi pihak luar mengenai perusahaan menyebabkan mereka melindungi diri dengan memberikan harga yang rendah untuk perusahaan. Manajer dalam suatu perusahaan perlu untuk menyajikan laporankeuangan perusahannya secara akurat dan tidak overstate agar mendapatkankepercayaan dari pihak luar. Informasi tidak hanya berupa laporan keuangantetapi juga bisa jadi merupakan alat promosi bagi para investor maupun kreditor.Informasi tersebut sangat penting bagi pelaku bisnis maupun investor karena haltersebut dapat memberikan gambaran baik untuk keadaan masa lalu, masa kinidan masa mendatang bagi keberlangsungan hidup perusahaan (Adrian, 2011).

Selain itu informasi tersebut juga dapat memberikan gambaran mengenai kinerja perusahaan. Informasi inilah yang dapat mempengaruhi pengambilan keputusan investor maupun kreditor dalam berinvestasi dan mengenai apa yang sudah dilakukan oleh manajemen untuk merealisasikan keinginan pemilik. Informasi ini berupa pemberian peringkat obligasi yang dipublikasikan diharapkan dapat menjadi sinyal kondisi keuangan perusahaan dan menggambarkan kemungkinan yang terjadi terkait dengan utang yang dimiliki. Seorang pemilik modal yang berminat membeli obligasi, sudah seharusnya memperhatikan peringkat obligasi karena peringkat tersebut memberikan informasi dan memberikan sinyal tentang kemungkinan kegagalan utang pada suatu perusahaan (Magreta \& Nurmayanti, 2019).

Berdasarkan Keputusan Ketua BAPEPAM dan Lembaga Keuangan Nomor: 135/BL/2006 Tentang "Pemeringkatan Atas Efek Bersifat Utang" menyatakan bahwa emiten yang akan menerbitkan obligasi wajib memperoleh hasil pemeringkatan obligasi. Hasil pemeringkatan tersebut diterbitkan oleh lembaga pemeringkat yang telah mendapat izin usaha sebagai lembaga pemeringkat dari Badan Pengawas Pasar Modal dan Lembaga Keuangan. Di Indonesia terdapat lembaga pemeringkat obligasi yaitu PEFINDO (Pemeringkat Efek Indonesia). Lembaga pemeringkat memberikan peringkat obligasi setiap satu tahun sekali selama obligasi tersebut belum lunas. Pemeringkatan antara perusahaan satu dan lainnya tidak dilakukan serentak seluruh perusahaan melainkan secara terpisah sesuai dengan perjanjian yang telah disepakati masing-masing perusahaan 
dengan lembaga rating.

Laba ditahan timbul sebagai hasil dari kegiatan perusahaan, yaitu laba bersih (Riyanto, 2011). Sebagian dari laba bersih ini akan ditahan atau diinvestasikan kembali ke dalam perusahaan. Laba ditahan biasanya ada pada perusahaan perseroan terbatas (PT), kegunaan dalam mengetahui besarnya laba ditahan dalam suatu perusahaan adalah untuk mengetahui kinerja pertumbuhan perusahaan tersebut dari tahun ke tahun. Pada setiap akhir periode akuntansi, laba bersih yang dihasilkan selama periode berjalan akan ditutup ke akun laba ditahan. Peristiwa pengumuman dividen (baik dividen tunai maupun dividen saham) kepada pemegang saham juga akan ditutup ke akun laba ditahan. Laba bersih yang dihasilkan selama periode berjalan akan menambah jumlah laba ditahan yang ada pada awal periode, sedangkan dividen yang diumumkan selama periode berjalan akan mengurangi atau memperkercil laba ditahan.

Laba operasi mengukur kinerja fundamental operasi perusahaan dan dihitung sebagai selisih antara laba kotor dengan beban operasional. Laba operasi diperoleh dari penjualan setelah dikurangi dengan beban, yaitu HPP dan beban operasi. Jadi, HPP merupakan salah satu unsur beban tersebut. Biasanya, HPP merupakan beban yang terbesar dari kegiatan utama perusahaan. Hasil penelitian ini menunjukkan bahwa laba operasi tidak diperhitungkan dalam menentukan peringkat obligasi jika dilihat secara parsial.

Laporan arus kas merupakan laporan yang menunjukkan arus kas masuk dan arus keluar pada suatu perusahaan. Arus kas masuk berupa pendapatan atau pinjaman dari pihak lain. Adapun arus kas keluar merupakan biaya-biaya yang telah dikeluarkan perusahaan (Kasmir, 2011).

Tujuan utama dari laporan arus kas adalah untuk memberikan informasi tentang penerimaan kas dan pengeluaran kas entitas selama satu periode. Tujuan lainnya adalah untuk menyediakan informasi tentang kegiatan operasi, investasi, dan pembiayaan entitas tersebut atas dasar kas (Mahendra,2014). Operating Cash Flow merupakan kas yang berasal dari aktivitas operasi atau kas yang berasal dari aktivitas utama perusahaan. Angka yang menunjukkan nilai operating cash flow dapat dilihat dalam laporan arus kas perusahaan.

Rasio leverage merupakan rasio yang menunjukkan tingkat proporsi penggunaan utang dalam membiayai investasi. Semakin besar rasio leverage pada suatu perusahaan, semakin besar pula risiko kegagalan perusahaan. Semakin rendah leverage perusahaan, semakin baik peringkat yang diberikan terhadap perusahaan (Raharja \& Sari, 2008). Hal itu mengindikasikan perusahaan dengan tingkat leverage yang tinggi cenderung memifliki kemampuan yang rendah dalam memenuhi kewajibannya.

Profitabilitas adalah kemampuan perusahaan memperoleh laba dalam hubungannya dengan penjualan, total aktiva maupun modal sendiri. Profitabilitas dapat memberikan gambaran atas suatu perusahaan mengenai seberapa efektif perusahaan beroperasi sehingga dapat menghasilkan keuntungan. Tingkat profitabilitasyang tinggi juga dapat mengindikasikan kemampuan perusahaan untuk going concern dan memenuhi kewajiban. Menurut (Raharja \& Sari, 2008) semakin tinggi tingkat profitabilitas perusahaan maka semain rendah risiko ketidakmampuan membayar (default) dan semakin baik peringkat yang diberikan terhadap perusahaan tersebut.

Model penelitian dalam penelitian ini dinyatakan dalam hipotesis sebagai berikut:

\section{Pengaruh Laba Ditahan terhadap Peringkat Obligasi}

Laba ditahan (retained earning) merupakan salah satu dari sumber dana yang paling penting untuk membiayai pertumbuhan perusahaan sehingga dapat dijadikan indikator bagi perusahaan untuk memberikan sinyal kepada investor mengenai kemampuannya dalam membayar kewajibannya (Riyanto, 2011). Jika pertumbuhan laba ditahan perusahaan tinggi maka biaya tersebut dapat digunakan dalam membiayai pertumbuhan perusahaan yang akhirnya dapat meningkatkan peringkat obligasi dari perusahan, ini sesuai dengan hasil penelitian yang dilakukan oleh (Estiyanti \& Yasa, 2012) yang menyatakan bahwa laba ditahan berpengaruh positif terhadap peringkat obligasi. Hal yang sama dikemukakan dalam penelitian (Syaifullah \& Soemantri, 2016) menemukan bahwa laba ditahan berpengaruh positif pada peringkat obligasi. Namun tanggapan tersebut berbeda dengan penelitian (Magreta \& Nurmayanti, 2019) menyatakan bahwa laba ditahan tidak berpengaruh pada peringkat obligasi di Bursa Efek Indonesia.

H1: Laba ditahan berpengaruh positif terhadap peringkat obligasi di Bursa Efek Indonesia.

\section{Pengaruh Laba Operasi terhadap Peringkat Obligasi}


(Wild \& Subramanyam, 2009) menyatakan bahwa laba operasi (operating income) merupakan suatu pengukuran laba perusahaan yang berasal dari aktivitas operasi yang masih berlangsung. Ukuran laba operasi juga dapat dipakai untuk mengevaluasi kemampuan manajemen dalam menetapkan harga, melakukan promosi produk perusahaan dan mengelola hubungan dengan pelanggan dansupplier. (Yasa, 2010) menemukan bahwa variabel log natural laba operasi berpengaruh positif pada peringkat obligasi. Didukung oleh penelitian (Melia, 2015) menyatakan bahwa laba operasi menunjukkan hubungan positif dengan peringkat obligasi (sesuai peraturan Bursa EfekIndonesia).

H2 : Laba operasi berpengaruh positif terhadap peringkat obligasi di Bursa Efek Indonesia.

\section{Pengaruh Aliran Kas Operasi terhadap Peringkat Obligasi}

Aliran kas operasi merupakan arus kas yang berasal dari aktivitas operasi perusahaan. Aktivitas operasi (operating activities) merupakan aktivitas perusahaan yang terkait dengan laba (Subramanyan, 2010). Semakin tinggi aliran kas operasi kinerja perusahaan yang semakin baik dan diprediksikan akan menghasillkan laba yang lebih baik pada periode yang akan datang dan dapat menarikinvestor.Penelitian Nurhasanah (2003), Manurung (2008) dan Andrian (2010) menyimpulkan bahwa aliran kas operasi berpengaruh positif pada peringkat obligasi. Didukung oleh penelitian (Yasa, 2010) yang menyatakan bahwa aliran kas operasi berpengaruh positif pada peringkat obligasi. Indonesia.

H3: Aliran kas operasi berpengaruh positif terhadap peringkat obligasi di Bursa Efek

\section{Pengaruh Leverage terhadap Peringkat Obligasi}

Rasio leverage adalah mengukur seberapa besar perusahaan dibiayai dengan utang (Fahmi, 2014). Jika rasio ini cukup tinggi, maka hal tersebut menunjukkan tingginya penggunaan utang, sehingga hal ini dapat membuat perusahaan mengalami kesulitan keuangan, dan biasanya memiliki risiko kebangkrutan yang cukup besar.Hasil penelitian yang dilakukan oleh (Rika et al., 2011) dan (Yuliana, 2011) mengatakan bahwa leverage memberikan pengaruh negatif terhadap prediksi peringkat obligasi. Hal ini karena perusahaan dengan rasio leverage yang tinggi memiliki kecenderungan kemampuan yang rendah dalam memenuhi kewajibannya. Adapun hasil penelitian (Raharja \& Sari, 2008) menyimpulkan bahwa leverage berpengaruh negatif terhadap ratingobligasi.

$\mathrm{H} 4$ : Leverage berpengaruh negatif terhadap peringkat obligasi di Bursa Efek Indonesia.

Pengaruh Profitabilitas terhadap Peringkat Obligasi

Profitabilitas merupakan tingkat kemampuan perusahaan untuk menghasilkan laba.Profitabilitas yang tinggi pada perusahaan mencerminkan kinerja yang baik. Penerbit obligasi yang memiliki profitabilitas tinggi akan berperingkat baik karena laba yang dihasilkan dapat digunakan untuk melunasi kewajiban. (Almilia \& Devi, 2015) rasio profitabilitas yang diukur dengan ROA mempunyai pengaruh yang positif terhadap pertumbuhan laba karena rasio ini mengukur kemampuan perusahaan dalam menghasilkan laba bersih berdasarkan tingkat aset tertentu. Hasil penelitian lainnya dilakukan oleh Onji dkk, (2013) menyimpulkan bahwa profitabilitas berpengaruh positif terhadap peringkat obligasi.

H5 : Profitabilitas berpengaruh positif terhadap peringkat obligasi.

\section{METODE}

\section{Tempat, Obyek Penelitian, Populasi dan Metode Penentuan Sampel}

Penelitian ini dilakukan pada Bursa Efek Indonesia (BEI) khususnya pada perusahaan manufaktur tahun 2017-2019 dari www.idx.co.id serta data peringkat obligasi dari www.pefindo.com. Objek penelitian ini peringkat obligasi pada perusahaan manufaktur yang terdaftar di BEI Tahun 2017-2019. Populasi dalam penelitian ini adalah perusahaan yang bergerak dibidang keuangan yang terdaftar di Bursa Efek Indonesia, menerbitkan obligasi, dan obligasinya terdaftar pada PT PEFINDO pada periode 2017 -2019. Sampel dalam penelitian ini dipilih menggunakan penyampelan bersasaran (purposive sampling). Adapun kriteria penentuan sampel adalah sebagai berikut:

Perusahaan manufaktur yang terdaftar di Bursa Efek Indonesia (BEI) dan menerbitkan obligasi 
periode tahun 2017-2019

Perusahaan manufaktur yang diperingkatioleh PT. PEFINDO

Perusahaan manufaktur di BEI yang memiliki kelengkapan data terkait dengan variabel penelitian.

\section{Data dan Sumber Data}

Data yang digunakan dalam penelitian ini adalah data sekunder dengan sumber data berasal dari www.idx.co.id dan www.pefindo.com.

\section{Metode Analisis Data}

Penelitian ini menggunakan metode analisis data yaitu Regresi Logistik. Tahapan analisis data yaitu: (1)statistik deskriptif; (2) uji regresi logistik meliputi uji kelayakan model regresi, uji keseluruhan model, matriks klasifikasi, uji koefisien determinasi, uji multikolinearitas dan model regresi terbentuk; Persamaan regresi logistik dirumuskan sebagai berikut:

$$
L n=\frac{\mathrm{PO}}{1-\mathrm{PO}}=\beta 0+\beta 1 \mathrm{LD}+\beta 2 \mathrm{LO}+\beta 3 \mathrm{AKO}+\beta 4 \mathrm{LEV}+\beta 5 \mathrm{~PB}+\varepsilon
$$

\section{HASIL DAN PEMBAHASAN}

\section{Statistik Deskriptif}

Table 1

Descriptive Statistics

Descriptive Statistics

\begin{tabular}{|l|r|r|r|r|r|}
\hline & N & Minimum & Maximum & \multicolumn{1}{c|}{ Mean } & Std. Deviation \\
\hline PO & 75 & .00 & 1.00 & .9200 & .27312 \\
LD & 75 & -.01 & 4.20 & .2828 & .73975 \\
LO & 75 & -744.86 & 5062396 & 198742.2 & 764929.61949 \\
AKO & 75 & -.67 & 2.06 & .0206 & .26814 \\
LEV & 75 & .01 & 5.57 & .3461 & .95374 \\
PB & 75 & -.12 & .84 & .0563 & .16229 \\
Valid N (listwise) & 75 & & & & \\
\hline
\end{tabular}

Output tampilan Statistical Product and Service Solution (SPSS) menunjukkan jumlah sampel yang digunakan sebanyak 25 (n). Berikut penjelasan tabel 5.1 :

Bahwa variabel Peringkat Obligasi (PO) memiliki nilai minimum 0,00 dan nilai maximum 1,00 dengan rata-rata (mean) 0,9200 dan standar deviasi sebesar 0,27312.

Variabel Laba Ditahan (LD) yang memiliki nilai minimum sebesar -0,01 dan nilai maximum sebesar 4,20 dengan nilai rata - rata (mean) sebesar 0,2828. Nilai standar deviasi sebesar 0,73975.

Variabel Laba Operasi (LO) memiliki nilai minimum sebesar $-744,86$ dan nilai maximum sebesar 5062396 dengan nilai rata - rata (mean) adalah 198742,2. Nilai standar deviasi sebesar $764929,61949$.

Variabel Aliran Kas Operasi (AKO) memiliki nilai minimum -0,67 dan nilai maximum sebesar 2,06 dengan nilai rata - rata (mean) adalah 0,0206 dan nilai standar deviasi sebesar 0,26814.

Variabel Leverage (LEV) memiliki nilai minimum 0,01 dan nilai maximum 5,57 dengan nilai rata - rata (mean) 0,3461 dan nilai standar deviasi sebesar 0,95374.

Variabel Profitabilitas (PB) memiliki nilai minimum -0,12 dan nilai maximum sebesar 0,84 dengan nilai rata - rata (mean) adalah 0,0563 dan nilai standar deviasi sebesar 0,16229.

\section{Hasil Uji Regresi Logistik}

\section{Kelayakan Model Regresi}


Table 2

Hosmer and Lemeshow Test

Hosmer and Lemeshow Test

\begin{tabular}{|l|r|r|r|}
\hline Step & Chi-square & \multicolumn{1}{c|}{ df } & \multicolumn{1}{c|}{ Sig. } \\
\hline 1 & 6.393 & & 7 \\
\hline
\end{tabular}

Nilai statistik Hosmer and Lemeshow's Goodness of Fit Test sebesar 6,393 dengan nilai signifikan sebesar 0,495. Dari hasil tersebut terlihat bahwa nilai signifikan lebih besar dari 0,05 .

\begin{tabular}{|c|c|}
\hline $\begin{array}{c}-2 \text { Log Likelihood } \\
\text { Block Number }=0\end{array}$ & $\begin{array}{c}-2 \text { Log Likelihood } \\
\text { Block Number }=1\end{array}$ \\
\hline 41,815 & 24,281 \\
\hline
\end{tabular}

\section{Matriks Klasifikasi}

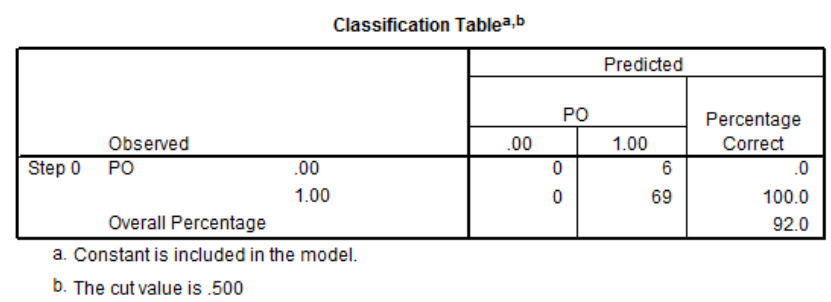

Tampilan tabel tersebut menunjukkan kekuatan prediksi dari model regresi untuk memprediksi peringkat obligasi yaitu 100 persen hal ini menunjukkan bahwa dengan menggunakan model regresi tersebut, terdapat sebanyak 69 perusahaaan atau 100 persen yang di prediksi akan menyajikan peringkat obligasi dari total 69 perusahaan yang mempublikasikan peringkat obligasi. Kekuatan prediksi dari model regresi untuk memprediksi kemungkinan perusahaan tidak berdasarkan peringkat obligasi adalah sebesar 0 persen. Dengan model regresi tersebut artinya tidak terdapat peringkat obligasi dari total 6 perusahaan. Dengan demikian persentase prediksi secara keseluruhan adalah 92 persen.

\section{Koefisien Determinasi(Nagelkerke's $R$ square)}

\begin{tabular}{|l|c|c|c|}
\hline Step & $\begin{array}{c}-2 \text { Log } \\
\text { likelihood }\end{array}$ & $\begin{array}{c}\text { Cox \& Snell } \\
\text { R Square }\end{array}$ & $\begin{array}{c}\text { Nagelkerke } \\
\text { R Square }\end{array}$ \\
\hline 1 & $24.281^{a}$ & .208 & .488 \\
\hline
\end{tabular}

Nilai Nagelkerke $R$ square sebesar 0,488 . Hal ini berarti variabilitas variabel dependen yang dapat dijelaskan oleh variabilitas variabel independen sebesar 48.8 persen sedangkan sisanya 51.2 persen dijelaskan oleh variabel lain yang tidak digunakan dalam penelitian ini.

\section{Uji Multikolinearitas}

\begin{tabular}{|ll|r|r|r|r|r|r|}
\multicolumn{7}{c|}{ Correlation Matrix } \\
\hline & & Constant & \multicolumn{1}{c|}{ LD } & \multicolumn{1}{c|}{ LO } & \multicolumn{1}{c|}{ AKO } & \multicolumn{1}{c|}{ LEV } & \multicolumn{1}{c|}{ PB } \\
\hline Step & Constant & 1.000 & -.069 & .035 & -.082 & -.753 & -.357 \\
& LD & -.069 & 1.000 & .035 & -.474 & -.458 & -.349 \\
& LO & .035 & .035 & 1.000 & -.017 & -.055 & -.040 \\
& AKO & -.082 & -.474 & -.017 & 1.000 & .126 & .046 \\
& LEV & -.753 & -.458 & -.055 & .126 & 1.000 & .568 \\
& PB & -.357 & -.349 & -.040 & .046 & .568 & 1.000 \\
\hline
\end{tabular}


Hasil pengujian menunjukkan tidak ada nilai koefisien korelasi antar variabel independen yang nilainya lebih besar dari 0,8 maka dapat disimpulkan tidak terdapat indikasi adanya multikolinearitas antar variabel independennya.

\section{Model Regresi Logistik Terbentuk}

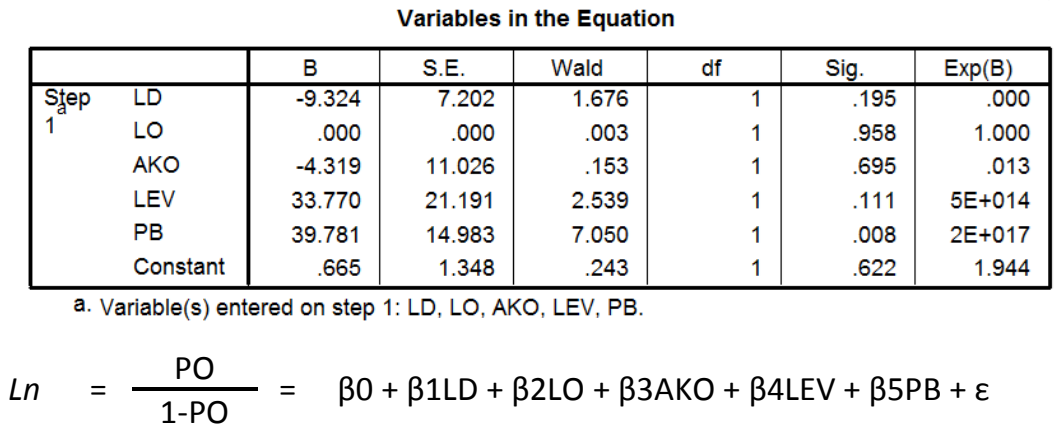

Hasil pengujian regresi logistik menghasilkan model sebagai berikut :

Berdasarkan model regresi yang terbentuk, dapat diinterpretasikan hasil sebagai berikut :

Nilai konstanta sebesar 0,665 artinya jika nilai variabel Laba Ditahan (LD), Laba Operasi (LO), Aliran Kas Operasi (AKO), Leverage (LEV), dan Profitabilitas (PB) dianggap konstan atau sama dengan 0 maka probabilitas sebesar 0,665.

Nilai koefisien regresi untuk variabel Laba Ditahan (LD) sebesar -9,324 dengan tingkat signifikansi sebesar 0,195 lebih besar 0,05 (5 persen). Ini berarti bahwa laba ditahan tidak berpengaruh terhadap peringkat obligasi sehingga $\mathrm{H}_{1}$ ditolak.

Nilai koefisien regresi Laba Operasi (LO) sebesar 0,000 dengan nilai signifikansi sebesar 0,958 lebih besar 0,05 ( 5 persen), dengan demikian laba ditahan tidak berpengaruh terhadap peringkat obligasi sehingga $\mathrm{H}_{2}$ ditolak.

Nilai koefisien regresi Aliran Kas Operasi (AKO) sebesar -4,319 dengan nilai signifikansi sebesar 0,695 lebih besar dari 0,05 (5 persen), dengan demikian aliran kas operasi tidak berpengaruh terhadap peringkat obligasi sehingga $\mathrm{H}_{3}$ ditolak.

Nilai koefisien regresi Leverage (LEV) sebesar 33,770 dengan nilai signifikansi sebesar 0,111 lebih besar dari 0,05 (5 persen), dengan demikian leverage tidak berpengaruh terhadap peringkat obligasi sehingga $\mathrm{H}_{4}$ ditolak.

Nilai koefisien regresi Profitabilitas (PB) sebesar 39,781 dengan nilai signifikansi sebesar 0,008 lebih kecil dari 0,05 (5 persen), dengan demikian profitabilitas berpengaruh terhadap peringkat obligasi sehingga $\mathrm{H}_{5}$ diterima.

\section{Pembahasan Hasil Penelitian}

Hipotesis pertama $(\mathrm{H} \square)$ menyatakan bahwa laba ditahan berpengaruh positif terhadap peringkat obligasi. Hasil pengujian hipotesis menunjukan laba ditahan tidak berpengaruh terhadap peringkat obligasi, dengan demikian hipotesis pertama ditolak. Sesuai dengan hasil analisis disimpulkan bahwa laba ditahan tidak mempengaruhi kenaikan peringkat obligasi perusahaan yang dikategorikan dalam invesmentgrade dan speculative grade.

Hipotesis kedua $(\mathrm{H} \square)$ menyatakan bahwa laba operasi berpengaruh positif terhadap peringkat obligasi. Hasil penelitian hipotesisis ini menunjukkan bahwa laba operasi tidak berpengaruh dalam menentukan peringkat obligasi. Hal ini dikarenakan dalam proses penilaian, perusahaan pemeringkat tidak mendasarkan pada laba operasinya, tetapi melihat laporan laba rugi perusahaan pada bagian bottom line sehingga labanya positif disebabkan karena besarnya pendapatan lain-lain.

Hipotesis ketiga $(\mathrm{H} \square)$ menyatakan aliran kas operasi berpengaruh positif terhadap peringkat obligasi. Hasil pengujian hipotesis ini menunjukan bahwa aliran kas operasi tidak berpengaruh terhadap peringkat obligasi dengan demikian hipotesis ketiga ditolak. Sesuai dengan hasil analisis disimpulkan bahwa kenaikan aliran kas operasi tidak mempengaruhi kenaikan peringkat obligasi perusahaan yang termasuk kategori investment grade dan speculative grade. Hasil penelitian ini mengidikasikan bahwa aliran kas operasi tidak diperhitungkan dalam menentukan peringkat obligasi.

Hipotesis keempat $(\mathrm{H} \square)$ menyatakan leverage berpengaruh negatif terhadap peringkatobligasi. 
Hasil pengujian hipotesis keempat menunjukkan bahwa leverage tidak berpengaruh terhadap peringkat obligasi, dengan demikian hipotesis keempat ditolak. Sesuai dengan penelitian ini mengindikasikan bahwa leverage tidak berpengaruh terhadap peringkat obligasi. Hal ini dikarenakan leverage merupakan kemampuan aktiva perusahaan yang dibiayai olehutang.

Hipotesis kelima $(\mathrm{H} \square)$ menyatakan profitabilitas yang diproksikan dengan Return on Asset (ROA) berpengaruh positif terhadap peringkat obligasi. Hasil pengujian menunjukkan bahwa hipotesis kelima profitabilitas berpengaruh positif terhadap peringkat obligasi, dengan demikian hipotesis keempat diterima. Hal ini dikarenakan profitabilitas yang tinggi pada perusahaan dapat mengukur pertumbuhan laba dalam menghasilkan laba bersih.

\section{SIMPULAN}

Faktor-faktor yang mempengaruhi peringkat obligasi yang terdiri yakni Profitabilitas terbukti berpengeruh positif, sementara Laba Ditahan, Laba Operasi, Aliran Kas Operasi, dan Leverage tidak berpengaruh terhadap peringkat obligasi.

\section{DAFTAR PUSTAKA}

Almilia, \& Devi. (2015). Faktor-faktor yang Mempengaruhi Prediksi Peringkat Obligasi pada Perusahaan Manufaktur yang Terdaftar di Bursa Efek Jakarta. In Proceeding Seminar Nasional Manajemen SMART. Bandung.

Estiyanti, \& Yasa. (2012). Pengaruh Faktor Keuangan dan Non Keuangan pada Peringkat Obligasi di Bursa Efek Indonesia. Banjarmasin. No034-AKPM-53: Simposium NasionalAkuntansi XV.

Fahmi. (2014). Analisis Laporan Keuangan. Bandung: Alfabeta.

Junaedi. (2016). Akuntansi Keuangan. Bandung: Ghaila Indonesia.

Kieso. (2018). A kuntansi Intermediate. Jakarta: Erlangga.

Magreta, \& Nurmayanti. (2019). Faktor-faktor yang Mempengaruhi Prediksi Peringkat Obligasi Ditinjau dari Faktor Akuntansi dan Non-Akuntansi. Jurnal Bisnis Dan Akuntansi, 11(3). Retrieved from https:// media.neliti.com/media/publications/321652-faktor-faktor-yang-mempengaruhi-prediksi-

2babd431.pdf

Melia, A. (2015). Pengaruh Good Corporate Governance terhadap kinerja perusahaan sector keuangan. Business Accounting Review, 3(1). Retrieved from http://publication.petra.ac.id/index.php/akuntansibisnis/article/view/2763

Raharja, \& Sari. (2008). Kemampuan Rasio Keuangan Dalam Memprediksi Peringkat Obligasi (PT. Kasnic Credit Rating). Jurnal MAKSI, 8(2), 212-232.

Rika, Budiatmanto, Prabowo, \& Arifin, T. (2011). Analisis Faktor-Faktor Yang Memperngaruhi Prediksi Peringkat Obligasi Pada Perusahaan Keuangan Yang Terdaftar Di Busa Efek Indonesia. Aceh: Simposium Nasional Akuntansi XIV Aceh.

Riyanto. (2011). Dasar - Dasar Pembelanjaan Perusahaan. Yogyakarta: YBPFE UGM.

Sari, \& Bandi. (2010). Praktik Manajemen Laba Terkait Peringkat Obligasi. Universitas Jenderal Soedirman Purwokerto: Simposium Nasional Akuntansi XIII.

Syaifullah, S., \& Soemantri, D. O. (2016). Pengaruh Kualitas Website Menggunakan Metode WEBQUAL 4.0 (Studi Kasus: CV. Zamrud Multimedia Network). Jurnal Reakyasa Dan Manajemen Sistem Informas, 2(1), 19-22. Retrieved from http://ejournal.uin-suska.ac.id/index.php/RMSI/article/ view/1689

Wild, J., \& Subramanyam, K. . (2009). Analisa Laporan Keuangan (Kesepuluh). Jakarta: Selemba Empat.

Yasa. (2010). Pemeringkatan Obligasi Perdana Sebagai Pemicu Manajemen Laba: Bukti Empiris dari Pasar 
Wacana Ekonomi (Jurnal Ekonomi Bisnis dan Akuntansi), 20 (1) 2021, 37

Laba Ditahan, Laba Operasi, Aliran Kas Operasi, Leverage, Profitabilitas Dan Pengaruhnya Pada Peringkat Obligasi

Modal Indonesia. Simposium Nasional Akuntansi XIII Purwokerto.

Yuliana. (2011). Pengaruh Pengumuman Peringkat Terhadap Kinerja Obligasi. Simposium Nasional Akuntansi VIII.Solo.

www.pefindo.com

www.idx.co.id 